\title{
EKSPERIMENTASI PEMBELAJARAN MATEMATIKA DENGAN MENGGUNAKAN MODEL PEMBELAJARAN PROBLEM SOLVING DAN MODEL PEMBELAJARAN KOOPERATIF TIPE TEAM ASSISTED INDIVIDUALIZATION (TAI) PADA POKOK BAHASAN PERSAMAAN DAN PERTIDAKSAMAAN LINEAR SATU VARIABEL DITINJAU DARI MINAT BELAJAR SISWA SMP NEGERI SE-KABUPATEN REMBANG
}

\author{
Eriska Fitri Kurniawati, Tri Atmojo Kusmayadi, \\ Suyono
}

\begin{abstract}
Abstrak
Tujuan penelitian ini adalah untuk mengetahui: (1) manakah yang memberi prestasi belajar matematika yang lebih baik, siswa yang dikenai model pembelajaran Problem Solving atau model pembelajaran kooperatif tipe TAI. (2) manakah yang memberikan prestasi belajar matematika yang lebih baik, siswa yang mempunyai minat belajar tinggi, sedang, atau rendah. (3) pada masing-masing tingkatan minat belajar siswa (tinggi, sedang, dan rendah), manakah yang memberikan prestasi belajar lebih baik antara model pembelajaran Problem Solving atau model pembelajaran kooperatif tipe TAI.

Penelitian ini merupakan penelitian eksperimental semu dengan desain faktorial $2 \times 3$. Populasi penelitian ini adalah seluruh peserta didik SMP di Kabupaten Rembang. Pengambilan sampel dilakukan dengan teknik stratified cluster random sampling. Sampel dalam penelitian ini sebanyak 194 peserta didik, dengan rincian 94 siswa pada kelas eksperimen satu dan 100 siswa pada kelas eksperimen dua. Pengumpulan datanya dilakukan melalui tes pilihan ganda dan angket minat belajar siswa. Uji coba instrumen tes meliputi validitas isi, tingkat kesukaran, daya pembeda, dan realibilitas. Uji prasyarat meliputi uji normalitas populasi menggunakan metode Lilliefors dan uji homogenitas variansi populasi menggunakan Bartlett. Dengan $\alpha=0,05$, diperoleh simpulan bahwa sampel berasal dari populasi yang berdistribusi normal dan mempunyai variansi yang homogen. Pengujian hipotesis menggunakan analisis variansi dua jalan dengan sel tak sama.

Berdasarkan hasil pengujian hipotesis, diperoleh simpulan bahwa: (1) model pembelajaran Problem Solving memberikan prestasi belajar matematika siswa yang lebih baik dibandingkan dengan model pembelajaran kooperatif tipe TAI. (2) prestasi belajar matematika siswa yang mempunyai minat belajar tinggi lebih baik daripada siswa yang mempunyai minat belajar sedang maupun rendah dan siswa yang mempunyai minat belajar sedang mempunyai prestasi belajar yang sama baik dengan siswa yang mempunyai minat belajar rendah. (3) model pembelajaran Problem Solving memberikan prestasi belajar matematika yang lebih baik dibandingkan dengan model pembelajaran kooperatif tipe TAI baik untuk siswa dengan minat belajar tinggi, sedang, maupun rendah. Sedangkan prestasi belajar matematika siswa yang mempunyai minat belajar tinggi lebih baik daripada siswa yang mempunyai minat belajar sedang maupun rendah dan siswa yang mempunyai minat belajar sedang mempunyai prestasi belajar yang sama baik dengan siswa yang mempunyai minat belajar rendah baik untuk siswa yang diberi model pembelajaran Problem Solving maupun model pembelajaran kooperatif TAI.
\end{abstract}

Kata Kunci : Minat Belajar, Pembelajaran kooperatif, Problem Solving, Team Assisted Individualization, Prestasi Belajar Matematika.

\section{PENDAHULUAN}

Matematika perlu diberikan kepada semua siswa mulai dari sekolah dasar sampai dengan sekolah menengah atas untuk membekali mereka dengan kemampuan berpikir logis, analitis, sistematis, kritis, dan kreatif, serta kemampuan bekerjasama. Di dalam Kurikulum Tingkat Satuan Pendidikan (KTSP) disebutkan bahwa pelajaran matematika bertujuan agar siswa 
memiliki kemampuan dalam hal (1)

memahami konsep matematika,

menggunakan penalaran, (3) memecahkan masalah, (4) mengkomunikasikan gangguan, dan (5) memiliki sikap menghargai kegunaan matematika dalam kehidupan.

Berdasarkan penelitian yang dilakukan oleh TIMSS (Trends in International Mathematics and Science Study) yang dipublikasikan 15 Agustus 2011, jumlah jam pengajaran matematika di Indonesia jauh lebih banyak dibandingkan Malaysia dan Singapura. Dalam satu tahun, siswa kelas 7 di Indonesia rata-rata mendapat 169 jam pelajaran matematika. Sementara di Malaysia hanya mendapat 120 jam dan Singapura 112 jam. Tapi kenyataannya, prestasi Indonesia berada jauh di bawah kedua negara tersebut. Prestasi matematika siswa Indonesia hanya menembus skor ratarata 397. Sementara itu, Malaysia mencapai 474 dan Singapura 593 (307 = rendah, 463 = menengah, $598=$ tinggi, dan $500=$ tingkat lanjut). Artinya "Waktu yang dihabiskan siswa Indonesia di sekolah tidak sebanding dengan prestasi yang diraih". (zainurie.wordpress.com).

Rendahnya prestasi matematika siswa tingkat nasional dipengaruhi oleh berbagai aspek. Salah satu pengaruhnya adalah rendahnya prestasi matematika siswa tingkat propinsi bahkan tingkat kabupaten/kota. Kondisi tersebut diperkuat oleh Laporan Hasil dan Statistika Nilai Ujian Nasional (UN) SMP Tahun Pelajaran 2008/2009. Secara nasional rerata nilai matematika siswa adalah 7,60, dengan nilai tertinggi 10,00 , terendah 0,25 dan standar deviasi 1,57 .

Berdasarkan Laporan Hasil dan Statistika Nilai Ujian Nasional (UN) SMP Tahun Pelajaran 2009/2010 diperoleh rerata nilai matematika siswa SMP Kota Rembang adalah 6,94 dengan nilai tertinggi 10,00, terendah 1,25 dan standar deviasi 2,01. Sedangkan rerata nilai matematika siswa SMP Propinsi Jawa Tengah adalah 7,30 dengan nilai tertinggi 10,00 , terendah 0,25 dan standar deviasi 1,74. Jika dibandingkan dengan rerata nasional dan propinsi, rerata nilai matematika siswa SMP Kota Rembang lebih rendah dari rerata nasional dan propinsi. Data tersebut membuktikan bahwa penguasaan materi pelajaran matematika siswa yang masih kurang.

Berdasarkan informasi dari berbagai guru matematika SMP di Kabupaten Rembang dan pengalaman beberapa peserta didik SMP di Kabupaten Rembang, mengemukakan bahwa salah satu kesulitan peserta didik adalah pada materi persamaan linear satu variabel. Informasi tersebut dipertegas oleh hasil analisis daya serap peserta didik SMP di Kabupaten Rembang pada Ujian Nasional tahun pelajaran 2009/2010. Hasil analisis serap terhadap kemampuan yang berkaitan dengan materi sistem persamaan linear satu variabel yang diujikan pada Ujian Nasional tahun pelajaran 2009/2010 menunjukkan bahwa penguasaan konsep sistem persamaan linear satu variabel oleh peserta didik SMP di 
Kabupaten Rembang kurang optimal Hal ini dapat dilihat pada tabel 1. dibanding tingkat Provinsi dan Nasional.

\section{Tabel 1. Penguasaan Konsep Peserta Didik SMP di Kabupaten Rembang Berkaitan dengan Materi Sistem Persamaan Linear Satu Variabel pada Ujian Nasional Tahun Ajaran 2009/2010}

\begin{tabular}{|c|c|c|c|c|}
\hline \multirow[t]{2}{*}{$\begin{array}{l}\text { No. } \\
\text { soal }\end{array}$} & \multirow[t]{2}{*}{ Kemampuan yang Diuji } & \multicolumn{3}{|c|}{$\begin{array}{c}\text { Persentase Penguasaan Konsep } \\
\text { (dalam \%) }\end{array}$} \\
\hline & & $\begin{array}{l}\text { Tingkat } \\
\text { Rayon }\end{array}$ & $\begin{array}{l}\text { Tingkat } \\
\text { Provinsi }\end{array}$ & $\begin{array}{l}\text { Tingkat } \\
\text { Nasional }\end{array}$ \\
\hline 12. & $\begin{array}{l}\text { Menyelesaikan masalah yang } \\
\text { berkaitan dengan sistem } \\
\text { persamaan linear satu variabel }\end{array}$ & 68,83 & 78,16 & 86,42 \\
\hline
\end{tabular}

(Sumber: Badan Standar Nasional Pendidikan)

Menurut data dan kenyataan di atas, kepada keaktifan siswa dalam membangun dapat disimpulkan bahwa belum pengetahuan mereka sendiri. Tentunya maksimalnya pendidikan matematika di Indonesia. Sehingga belum dapat meningkatkan kualitas kemampuan matematika siswa Indonesia. Dalam meningkatkan kualitas pendidikan matematika, selain jam pelajaran, perlu diketahui faktor-faktor yang mempengaruhi pendidikan matematika. Terdapat beberapa faktor yang mempengaruhi proses belajar mengajar matematika antara lain: strategi pembelajaran yang dipilih oleh guru, gaya belajar siswa, motivasi belajar siswa, minat belajar siswa, lingkungan belajar siswa dan tingkat kecerdasan siswa.

Ada kemungkinan penyebab rendahnya prestasi belajar matematika siswa pada saat ini adalah karena pelaksanaan pembelajaran matematika di sekolah itu masih bersifat konvensional (siswa pasif dan guru mendominasi proses pembelajaran). Dalam hal ini guru berusaha menyelesaikan bahan ajar dengan cara menyampaikan materi secara langsung kepada siswa. Cara seperti ini sangatlah bertentangan dengan teori konstruktivisme yang lebih menekankan pembelajaran yang seperti disebutkan di atas (guru sangat dominan), hendaknya ditinggalkan atau setidak tidaknya dikurangi.

Salah satu strategi pembelajaran yang dapat digunakan guru adalah strategi pembelajaran pemecahan masalah (Problem Solving) merupakan konsep belajar yang mengaitkan materi yang diajarkan dengan masalah yang dihadapi sehari-hari. Dalam stategi pembelajaran ini, siswa diharapkan dapat menyelesaikan masalah matematika sesuai dengan pemahaman masing-masing siswa berlandaskan pada pengetahuan yang telah dimiliki. Dengan strategi ini diharapkan pembelajaran semakin bermakna bagi siswa, sehingga apa yang sudah didapatkan tidak mudah lupa. Proses pembelajaran dengan Problem Solving berlangsung alamiah dalam bentuk kegiatan siswa bekerja dan mengalami, bukan hanya mentransfer pengetahuan dari guru ke siswa.

Selain strategi pembelajaran pemecahan masalah (Problem Solving), guru juga dapat menggunakan strategi pembelajaran kooperatif tipe Team Assisted 
Individualization (TAI). Menurut Amin Suyitno (2006:9), model pembelajaran kooperatif tipe TAI merupakan model pembelajaran yang membentuk kelompok kecil yang heterogen dengan latar belakang cara berpikir yang berbeda untuk saling membantu terhadap siswa yang lain yang membutuhkan bantuan. Dalam model ini, diterapkan bimbingan antar teman yaitu siswa yang pandai dapat bertanggung jawab terhadap siswa yang lemah. Di samping itu dapat meningkatkan partisipasi siswa yang lemah. Serta dapat pula meningkatkan partisipasi siswa dalam kelompok kecil. Siswa yang pandai dapat mengembangkan kemampuan dan keterampilannya, sedangkan siswa yang lemah dapat terbantu menyelesaikan permasalahan yang dihadapi

Faktor lain yang mempengaruhi proses belajar mengajar matematika yang dikemukakan oleh Lester dan Alice Crow dalam The Liang Gie (1995:129) adalah “An interest in learning is a obligation which goes with you to class and accompanies you during each study assignment, thereby, enabling you to succed in the study activity. Likewise, interest in basic to your life's work if you to reach your anticipated goal or goals. Interest in your work, in yourstudy or in your recreation projects is necessary for genuine success in the outcome”. Dari pendapat tersebut dapat disimpulkan minat merupakan dasar jika ingin mencapai keberhasilan dalam belajar atau memperoleh prestasi belajar yang baik. Minat belajar yang tinggi akan sangat berpengaruh dengan prestasi belajar.

Pendapat yang dikemukakan oleh Lisnawaty (1993: 58) bahwa minat belajar perlu mendapat perhatian yang khusus karena minat merupakan salah satu faktor penunjang keberhasilan proses belajar. Slameto (2003: 57) mengemukakan bahwa salah satu faktor internal yang sangat besar pengaruhnya terhadap proses belajar siswa adalah minat siswa itu sendiri, karena bila bahan pelajaran yang dipelajari tidak sesuai dengan minat siswa, maka siswa tidak akan belajar dengan sebaik-baiknya, karena tidak ada daya tarik baginya. Sebaliknya bila bahan pelajaran itu sesuai dengan minat siswa maka akan lebih mudah mempelajarinya karena minat menambah frekuensi belajar. Menurut Dalyono dalam Djamarah (2000:157) minat belajar yang tinggi cenderung menghasilkan prestasi yang tinggi sebaliknya minat belajar rendah akan menghasilkan prestasi yang rendah.

Selain itu, juga terdapat faktor eksternal yang merupakan faktor dari luar siswa. Faktor ini terdiri dari 2 macam yaitu lingkungan sosial dan lingkungan non sosial. Lingkungan sosial yang dapat berpengaruh terhadap kegiatan dan prestasi belajar siswa adalah lingkungan sekolah, lingkungan keluarga, dan lingkungan masyarakat. Sarana dan prasarana penunjang kegiatan belajar, kondisi fisik rumah, kondisi fisik perkampungan siswa dan waktu yang disenangi siswa untuk belajar termasuk 
dalam lingkungan non sosial yang mempengaruhi prestasi belajar siswa.

\section{Model Pembelajaran Problem Solving}

Pembelajaran dengan problem solving (pemecahan masalah) dipandang sebagai pembelajaran yang meningkatakan kemampuan siswa dalam berpikir tinggi. Karena siswa setiap harinya selalu dihadapkan pada suatu masalah, disadari atau tidak. Karena itu pembelajaran dengan problem solving sejak dini diperlukan agar siswa dapat menyelesaikan problematika kehidupannya. Dalam pembelajaran matematika ini aspek pemecahan masalah menjadi semakin penting. Ini dikarenakan matematika merupakan pengetahuan yang logis, sistematis, berpola, abstrak, dan yang tak kalah penting menghendaki pembuktian.

Istilah problem solving sering digunakan dalam berbagai bidang ilmu dan memiliki pengertian yang berbeda-beda pula. Tetapi problem solving dalam matematika memiliki kekhasan tersendiri. Secara garis besar terdapat tiga macam interpretasi istilah problem solving menurut Branca, N. A.dalam Krulik, S. \& Reys, R. E. (1980: 3-6) dalam pembelajaran matematika, yaitu:

1) Problem solving sebagai tujuan

Para pendidik, matematikawan, dan pihak yang menaruh perhatian pada pendidikan matematika seringkali menetapkan problem solving sebagai salah satu tujuan pembelajaran matematika. Bila problem solving ditetapkan atau dianggap sebagai tujuan pengajaran maka ia tidak tergantung pada soal atau masalah yang khusus, prosedur, atau metode, dan juga isi matematika. Anggapan yang penting dalam hal ini adalah bahwa pembelajaran tentang bagaimana menyelesaikan masalah (solve problems) merupakan "alasan utama" (primary reason) belajar matematika.

2) Problem solving sebagai proses Pengertian lain tentang problem solving adalah sebagai sebuah proses yang dinamis. Dalam aspek ini, problem solving dapat diartikan sebagai proses mengaplikasikan segala pengetahuan yang dimiliki pada situasi yang baru dan tidak biasa. Dalam interpretasi ini, yang perlu diperhatikan adalah metode, prosedur, strategi dan heuristik yang digunakan siswa dalam menyelesaikan suatu masalah. Masalah proses ini sangat penting dalam belajar matematika dan yang demikian ini sering menjadi fokus dalam kurikulum matematika. Sebenarnya, bagaimana seseorang melakukan proses problem solving dan bagaimana seseorang mengajarkannya tidak sepenuhnya dapat dimengerti. Tetapi usaha untuk membuat dan menguji beberapa teori tentang pemrosesan informasi atau proses problem solving telah banyak dilakukan. Dan semua ini memberikan beberapa prinsip dasar atau petunjuk dalam belajar problem solving dan aplikasi dalam pengajaran. 
3) Problem solving sebagai keterampilan dasar

Pengertian problem solving sebagai keterampilan dasar lebih dari sekedar menjawab tentang pertanyaan: apa itu problem solving?

Problem solving adalah suatu pendekatan pembelajaran dalam menghadapi masalah. Problem solving juga merupakan suatu prosedur yang didalamnya terdapat langkah-langkah yang harus diikuti dalam memecahkan sebuah masalah yang dihadapi seseorang sebagai perorangan atau seseorang bagai pemimpin organisasi atau anggota organisasi. Sedangkan menurut Dr.Marlow Ediger "problem solving is a vital skill for all to develop. Developmentally and at increasing levels of diffuculty, pupils must be able to solve personal mathematics problems". Yaitu pemecahan masalah adalah suatu keterampilan yang penting untuk berkembang. Saat perkembangan dan meningkatnya tingkat kesulitan, siswa harus mampu memecahkan masalah matematika secara pribadi.

Sedangkan menurut Polya (1945) "defines problem-solving as the process used to solve a problem that does not have obvious solutions" yaitu Polya mendefinisikan problem solving adalah proses untuk menyelesaikan masalah yang tidak mempunyai jawaban yang jelas. Adapun empat langkah cara menyelesaikan masalah menurut Polya (1971), yaitu:

1) Understand the problem (memahami masalah).
2) Devise a plan (buat sebuah rencana).

3) Carry out the plan (terapkan rencana tadi).

4) Look back (periksa kembali) (Sumardyono, 2006:24)

Pentingnya problem solving juga dapat dilihat pada perannya dalam pembelajaran. Stanic \& Kilpatrick seperti dikutip McIntosh, R. \& Jarret, D. (2000:8) dalam buku "Tips dalam Penerapan Pembelajaran Problem Solving" (Suyadi, 2009:27), membagi peran problem solving sebagai konteks menjadi beberapa hal:

1) Untuk pembenaran pengajaran matematika.

2) Untuk menarik minat siswa akan nilai matematika, dengan isi yang berkaitan dengan masalah kehidupan nyata.

3) Untuk memotivasi siswa, membangkitkan perhatian siswa pada topik atau prosedur khusus dalam matematika dengan menyediakan kegunaan kontekstualnya (dalam kehidupan nyata).

4) Untuk rekreasi, sebagai sebuah aktivitas menyenangkan yang memecah suasana belajar rutin.

5) Sebagai latihan, penguatan keterampilan dan konsep yang telah diajarkan secara langsung (mungkin ini peran yang paling banyak dilakukan oleh kita selama ini).

Suatu soal dapat dijadikan sebagai sarana dalam pembelajaran dengan problem solving, jika dipenuhi syarat-syarat antara lain: siswa memiliki pengetahuan prasyarat 
untuk mengerjakan soal yang diberikan, siswa belum tahu algoritma/cara pemecahan soal, soal terjangkau oleh siswa, siswa mau dan berkehendak untuk menyelesaikan soal. Sedangkan ciri-ciri suatu soal disebut "problem" dalam perspektif ini paling tidak memuat dua hal yaitu: soal tersebut menantang pikiran (challenging) dan soal tersebut tidak otomatis diketahui cara penyelesaiannya (non routine).

Jika problem solving ini diterapkan, maka langkah-langkah yang dapat ditempuh guru adalah sebagai berikut:

1) Guru mengajarkan materi pelajaran seperti biasanya, pemanfaatan alat peraga atau media masih dimungkinkan, apalagi untuk anak Sekolah Dasar.

2) Guru dengan tanya jawab memberikan contoh soal.

3) Guru memberikan satu atau dua soal yang harus dipecahkan siswa berdasarkan persyaratan soal sebagai sebuah problem solving.

Siswa dengan dipandu guru menyelesaikan soal yang dipakai sebagai bahan ajar dalam pembelajaran dengan problem solving (Suyadi, 2009:30)

\section{Model Pembelajaran Kooperatif tipe}

\section{TAI (Team Assisted Individualization)}

Model Pembelajaran Kooperatif Tipe TAI (Team Assisted Individualization) termasuk dalam pembelajaran kooperatif. Dalam model pembelajaran Team Assisted Individualization, siswa ditempatkan dalam kelompok-kelompok kecil (4-5) yang heterogen dan selanjutnya diikuti dengan pemberian bantuan secara individu bagi siswa yang memerlukannya. Dengan pembelajaran kelompok, diharapkan para siswa dapat meningkatkan pikiran kritisnya, kreatif, dan menumbuhkan rasa sosial yang tinggi. Sebelum dibentuk kelompok, siswa diajarkan bagaimana bekerjasama dalam suatu kelompok. Siswa dilatih menjadi pendengar yang baik, dapat memberikan penjelasan kepada teman sekelompok, berdiskusi, mendorong teman lain untuk bekerjasama, menghargai kemampuan siswa untuk bekerjasama dalam kelompok kecil yang heterogen. Masing-masing anggota dalam kelompok memiliki tugas yang setara. Karena pada pembelajaran kooperatif keberhasilan kelompok sangat diperhatikan, maka siswa yang pandai ikut bertanggung jawab membantu temannya yang lemah dalam kelompoknya. Dengan demikian, siswa yang pandai dapat mengembangkan kemampuan dan keterampilannya, sedangkan siswa yang lemah akan terbantu dalam memahami permasalahan yang diselesaikan dalam kelompok tersebut.

Model pembelajaran kooperatif tipe TAI merupakan model pembelajaran yang membentuk kelompok kecil yang heterogen dengan latar belakang cara berpikir yang berbeda untuk saling membantu terhadap siswa yang lain yang membutuhkan bantuan. Dalam model ini, diterapkan bimbingan antar teman yaitu siswa yang pandai dapat bertanggung jawab terhadap siswa yang lemah. Di samping itu dapat meningkatkan 
partisipasi siswa yang lemah. Serta dapat pula meningkatkan partisipasi siswa dalam kelompok kecil. Siswa yang pandai dapat mengembangkan kemampuan dan keterampilannya, sedangkan siswa yang lemah dapat terbantu menyelesaikan permasalahan yang dihadapi (Amin Suyitno, 2006:9).

Model pembelajaran kooperatif tipe $T A I$ memiliki 8 komponen (Amin Suyitno, 2006:10) yakni sebagai berikut.

a) Teams

Pembentukan kelompok heterogen yang terdiri atas 4-5 siswa.

b) Placement Test

Yakni pemberian pre-test kepada siswa atau melihat rata-rata nilai harian siswa agar guru mengetahui kelemahan siswa pada bidang tertentu.

c) Student Creative

Melaksanakan tugas dalam suatu kelompok dengan menciptakan situasi dimana keberhasilan individu ditentukan atau dipengaruhi oleh keberhasilan kelompoknya.

d) Team Study

Yaitu tahapan tindakan belajar yang harus dilaksanakan oleh kelompok dalam tahap ini guru dapat memberikan bantuan secara individual kepada siswa yang membutuhkannya.

e) Team Scores and Team Recognition

Yaitu pemberian skor terhadap hasil kerja kelompok dan memberikan kriteria penghargaan terhadap kelompok yang berhasil secara cemerlang dan kelompok yang dipandang kurang berhasil dalam menyelesaikan tugas.

\section{f) Teaching Group}

Yaitu pemberian materi singkat dari guru menjelang pemberian tugas kelompok.

g) Facts Test

Yaitu pelaksanaan tes-tes kecil berdasarkan fakta yang diperoleh siswa.

h) Whole Class Units

Yaitu pemberian materi oleh guru kembali ke akhir waktu pembelajaran dengan strategi pemecahan masalah (Amin Suyitno, 2006:10).

Dengan mengadopsi model pembelajaran TAI untuk mengajarkan suatu mata pelajaran pada siswa, maka tahapan pembelajaran TAI pada penelitian ini adalah sebagai berikut.

a) Guru menjelaskan kepada seluruh siswa tentang akan diterapkannya model pembelajaran Team Assisted Individualization, sebagai suatu variasi model pembelajaran. Guru menjelaskan kepada siswa tentang pola kerjasama antar siswa dalam suatu kelompok.

b) Guru menjelaskan materi secara singkat (mengadopsi komponen teaching group).

c) Guru membentuk kelompok-kelompok kecil yang beranggotakan 4-5 siswa dengan tingkat kepandaian yang heterogen dengan mempertimbangkan keharmonisan kerja kelompok (mengadopsi komponen teams).

d) Guru memberikan tugas kelompok dengan bahan yang telah disiapkan yaitu 
LKS siswa. Dengan buku paket dan LKS, melalui kerja kelompok, siswa mengisi LKS (mengadopsi komponen student creative)

e) Ketua kelompok melaporkan keberhasilan kelompoknya atau melapor kepada guru tentang hambatan yang dialami anggota kelompoknya. Jika diperlukan, guru dapat memberikan bantuan secara individual (mengadopsi komponen team study)

f) Ketua kelompok harus dapat menetapkan bahwa setiap anggota telah memahami materi bahan ajar yang diberikan guru, dan siap untuk diberi tes oleh guru (mengadopsi komponen team scores dan team recognition). Setelah diberi ulangan, guru harus mengumumkan hasilnya dan menetapkan kelompok terbaik sampai kelompok yang belum berhasil (jika ada).

g) Pada saat guru memberikan tes, tindakan ini mengadopsi komponen fact test.

h) Menjelang akhir waktu, guru memberikan latihan pendalaman secara klasikal dengan menekankan strategi pemecahan masalah (mengadopsi komponen whole class units).

i) Guru memberikan test formatif, sesuai dengan TPK/kompetensi yang ditentukan.

\section{Minat Belajar Siswa}

a. Pengertian Minat Belajar

Seseorang tidak akan merasa bosan menekuni sesuatu apabila dia memang mempunyai minat terhadap hal tersebut. Sehingga minat seseorang terhadap sesuatu akan mempengaruhi sikap dan perhatiannya.
Minat seseorang sering dikaitkan dengan perhatian, artinya untuk melihat ada tidaknya minat seseorang terhadap sesuatu dapat diketahui dari ada tidaknya perhatian terhadap hal tersebut.

Salah satu faktor yang mempengaruhi belajar adalah minat, karena bila bahan pelajaran yang dipelajari tidak sesuai dengan minat siswa, maka siswa tidak akan belajar dengan sebaik-baiknya. Bahan pelajaran yang menarik minat siswa, lebih mudah dipelajari dan disimpan, karena minat menambah kegiatan belajar.

Minat mempunyai peranan penting dalam dunia pendidikan, karena minat merupakan salah satu faktor yang memungkinkan siswa lebih konsentrasi, lebih semangat dan menimbulkan perasaan gembira sehingga siswa tidak mudah bosan, tidak mudah lupa dalam usahanya untuk belajar.

Pada hakekatnya secara psikis seseorang memiliki suatu kegiatan pada dirinya berbeda-beda, misalnya motivasi, minat, bakat dan sebagainya. Sedangkan minat sendiri merupakan ungkapan psikis yang sangat penting untuk mencapai suatu kebutuhan manusia.

Menurut Slameto (2003:180) minat adalah suatu rasa lebih suka dan rasa keterikatan pada suatu hal atau aktivitas tanpa ada yang menyuruh. Minat pada dasarnya adalah penerimaan akan suatu hubungan antara diri sendiri dengan sesuatu dari luar. Semakin kuat atau semakin dekat hubungan tersebut, semakin besar minatnya. 
Abu Ahmadi (1992:151) mengatakan bahwa antara minat dan perhatian pada umumnya dianggap sama atau tidak ada perbedaan. Memang keduanya hampir sama, dan dalam praktek selalu berhubungan satu sama lain. Apa yang menarik minat dapat menyebabkan adanya perhatian terhadap sesuatu tertentu disertai dengan minat.

Dari beberapa pengertian minat di atas terdapat kesamaan yaitu merupakan kesamaan psikis, adanya pemusatan perhatian terhadap obyek atau aktivitas tertentu.

Dari pernyataan di atas dapat ditarik kesimpulan bahwa minat belajar adalah pernyataan psikis yang menunjukkan seseorang untuk memusatkan perhatiannya pada kegiatan belajar dan untuk mempelajari sesuatu untuk mencapai tujuan belajar

Dalam hubungannya dengan belajar, minat merupakan salah satu unsur yang diperlukan dalam aktivitas belajar. Minat akan timbul jika memiliki harapan dan hasil partisipasi yang diperoleh dalam suatu aktivitas dengan demikian penunjang minat yang terpenting adalah kemampuan yang menuntut siswa untuk mengatur proses internalnya dalam mengendalikan, mempelajari, mengingat, dan berpikir tentang subyek yang diminatinya.

Oleh karena itu seorang guru dalam menyampaikan pelajaran harus mampu membuat siswa senang dalam belajar. Dengan adanya minat yang timbul maka besar juga usaha untuk mempelajari pelajaran tersebut dan diharapkan siswa memperoleh hasil yang baik.

\section{b. Macam-macam Minat Belajar}

Setelah diketahui penjelasan tentang minat, maka minat itu sendiri ada bermacam-macam. Minat merupakan salah satu pendorong keberhasilan proses belajar siswa.

Menurut Slavin (2010:64) ada tiga macam minat yaitu:

1) Minat yang diekspresikan (Exspressed interest)

Seseorang dapat mengungkapkan minat atau pilihannya dengan kata tertentu. Contoh : Seorang anak mengungkapkan pada orang tuanya bahwa kalau rajin belajar dan mendapat nilai hasil belajar baik, dia ingin melanjutkan ke Perguruan Tinggi (PT) yang terkenal di Indonesia.

2) Minat yang diwujudkan/manifestasikan (manifest Interest)

Seseorang dapat mengekspresikan minat bukan melalui kata-kata tetapi melalui tindakan atau perbuatan, ikut berperan aktif dalam suatu aktifitas tertentu. Contoh : Seseorang anak ikut terlibat dalam kegiatan ekstrakurikuler, anak aktif dalam kegiatan belajar mengajar.

3) Minat yang di inventarisasikan (Inventorist interest)

Seseorang menilai minatnya dapat diukur dengan menjawab pertanyaan terhadap sejumlah pertanyaan tertentu atau urutan pilihannya untuk kelompok 
aktifitas tertentu. Rangkaian pertanyaan semacam ini sering disebut Inventori minat. Jadi pada minat ini terdapat unsur pengenalan (kognitif) emosiemosi atau unsur afektif, dan kemauan atau unsur volutif, konatif untuk mencapai obyek atau tujuan.

Dari beberapa pendapat di atas dapat diperoleh gambaran bahwa minat yang ada pada seseorang sudah ada sejak lahir dan menjadi arah dalam segala tindakannya serta timbul karena adanya perasaan suka pada obyek. Sehingga segala kelakuan tindakan dan segala kegiatan yang tidak didasari minat yang kuat cenderung akan memberikan hasil belajar yang kurang baik, sebab antara minat dan kelakuan sangat erat hubungannya. Dengan demikian apabila siswa tidak mempunyai minat belajar yang sungguh-sungguh maka kemungkinan kurang optimal dalam mencapai prestasi yang baik, siswa yang berminat belajar dapat dilihat dari usahanya yang sungguh-sungguh dalam belajar baik di lingkungan sekolah maupun di rumah.

\section{c. Pentingnya Minat}

Setiap siswa yang menuntut ilmu harus melakukan konsentrasi dalam belajarnya. Konsentrasi dalam belajar adalah pemusatan pikiran terhadap suatu mata pelajaran dengan mengesampingkan semua hal lainnya yang tidak berhubungan dengan pelajaran tersebut. Tanpa konsentrasi tidak mungkin ia berhasil menguasai pelajarannya. Konsentrasi tidak ada atau kurang bilamana tidak terdapat minat yang memadai dalam diri siswa tersebut.

Pendapat Lester dan Alice Crow dalam The Liang Gie (1995:129) dibawah ini yang mengatakan bahwa:

"An interest in learning is a obligation which goes with you to class and accompanies you during each study assigment, thereby, enabling you to succed in the study activity. Like wise, interest in basic to your life's work if you to reach your anticipated goal or goals. Interest in your work, in you study or in your recreation projects is necessary for genuine success in the out come".

Hal tersebut dapat diartikan sebagai: suatu minat dalam belajar merupakan suatu kewajiban yang menyertai anda ke kelas dan menemani anda selama setiap tugas studi, dengan demikian memungkinkan anda berhasil dalam kegiatan studi. Demikian pula minat merupakan dasar dari tugas hidup anda kalau anda ingin mencapai tujuan atau tujuan-tujuan anda yang diharapkan. Minat dalam pekerjaan anda, dalam studi anda atau dalam kegiatan-kegiatan hiburan anda adalah perlu untuk sukses sejati dalam hasilnya.

d. Fungsi Minat dalam Belajar

Menurut Dalyono dalam Djamarah (2000:157) minat belajar yang tinggi cenderung menghasilkan prestasi yang tinggi sebaliknya minat belajar rendah akan menghasilkan prestasi yang rendah. Dalam kegiatan belajar sangat diperlukan adanya minat. Prestasi belajar akan menjadi optimal jika adanya minat yang tinggi pada diri 
siswa, makin tinggi minat belajar yang dimiliki siswa maka akan semakin bagus hasil belajar yang diperolehnya. Jadi dengan minat yang tinggi dan kemampuan siswa untuk melaksanakannya maka siswa akan senantiasa menentukan intensitas belajarnya.

Sehubungan dengan hal di atas maka fungsi minat adalah:

1) Mendorong manusia untuk bertindak sebagai penggerak yang melepaskan energi agar dapat menggerakkan setiap kegitan yang akan dikerjakannya.

2) Menentukan arah perbuatan yakni kearah tujuan yang ingin dicapai, dengan demikian minat memberikan arah dan kegiatan yang dilakukan sesuai dengan tujuan yang dicita-citakan.

3) Menyeleksi perbuatan, yakni menentukan perbuatan-perbuatan apa yang harus dikerjakan sesuai dengan apa yang di lakukan untuk mencapai tujuan dan mampu untuk memilah-milah kegiatan yang bermanfaat dengan kegiatan yang mendukung dalam pencapaian cita-cita tersebut.

\section{METODE PENELITIAN}

Penelitian ini, yakni siswa-siswa Kelas VII SMP Negeri di Kabupaten Rembang yang meliputi 54 SMP. Populasi ini kemudian dibagi menjadi 3 kategori, yaitu SMP yang mempunyai prestasi tinggi, sedang, dan rendah. Dalam pengkategorian SMP berdasarkan nilai rata-rata UN Matematika tahun pelajaran 2009/2010.
Penelitian ini menggunakan teknik pengambilan sampel Stratified Cluster Random Sampling yaitu dengan mengambil secara acak 3 sekolah yang ada dalam populasi yaitu 1 sekolah pada kelompok atas, 1 sekolah pada kelompok sedang dan 1 sekolah pada kelompok bawah dan masing masing sekolah diambil 2 kelas sebagai kelompok eksperimen 1 dan kelompok eksperimen 2. Untuk menentukan kelompok eksperimen 1 dan kelompok eksperimen 2 pada masing-masing sekolah sampel dengan melakukan undian. Undian dilakukan dengan mengambil 2 kelas dari banyaknya kelas paralel pada sekolah yang dijadikan sebagai sekolah sampel.

Data yang diperoleh dalam penelitian ini berupa 2 jenis data, yaitu data tentang prestasi belajar siswa dan data tentang tingkat minat belajar siswa. Data prestasi belajar meliputi 2 tahapan, yaitu tahap awal (nilai UN Matematika SD) dan tahap akhir (nilai tes prestasi belajar). Nilai UN Matematika SD diambil pada awal sebelum penelitian dilakukan dengan tujuan untuk mengetahui apakah sampel yang diambil berasal dari populasi yang normal, homogen dan seimbang. Tes prestasi belajar dilaksanakan setelah eksperimen dan tes ini digunakan untuk mengetahui prestasi belajar siswa setelah diadakan perlakuan. Sebelum eksperimen, dibagikan angket minat belajar siswa. Soal tes prestasi belajar dan angket minat belajar, sebelum dibagikan ke obyek penelitian, kedua instrumen ini telah diujicobakan. 
Untuk instrumen yang berupa angket diberlakukan pengukuran validitas, konsistensi internal dan reliabitas. Angket ini dibuat berdasarkan indikator dan disesuaikan dengan kemampuan obyek penelitian. Angket yang sudah dibuat diuji validitasnya dengan menggunakan prinsip uji validitas isi. Untuk menilai apakah suatu instrumen mempunyai validitas isi yang tinggi, yang biasanya dilakukan adalah melalui expert judgment (penilaian yang dilakukan oleh pakar). Adapun langkahlangkah yang dilakukan dalam uji validitas isi adalah membuat kisi-kisi angket, menyusun soal angket, dan menelaah butir angket.

\section{HASIL PENELITIAN}

Uji normalitas menggunakan data UN Matematika SD. Teknik yang digunakan dalam uji normalitas adalah uji Lilliefors. Hasil uji normalitas data UN Matematika SD kelompok eksperimen 1 dan kelompok 2 nampak pada Tabel 2.

Dari pengolahan angket minat belajar untuk kelompok eksperimen 1 dan 2 diperoleh rata-rata 77,317 dan standar deviasi 7,524 untuk perhitungan pada Lampiran 23. Hasil perhitungan rata-rata dan standar deviasi digunakan untuk menentukan tingkat minat belajar siswa, yaitu minat belajar tinggi jika hasil pengisian angket lebih besar dari 81,133, minat belajar sedang jika hasil pengisian angket berada pada interval 73,609 sampai dengan 81,133 dan minat belajar rendah jika hasil pengisian angket kurang dari 73,609.

\section{Data Prestasi Belajar Matematika}

Dari data prestasi belajar yang telah diperoleh, disajikan Tabel 4 dan Tabel 5.

Tabel 2. Rangkuman Hasil Uji Normalitas Data UN SD Matematika

\begin{tabular}{|l|l|l|l|l|l|}
\hline Kelompok & $\mathbf{L}_{\text {obs }}$ & $\mathbf{n}$ & $\mathbf{L}_{\text {tabel }}$ & Keputusan Uji & Kesimpulan \\
\hline eksperimen 1 & 0,0685 & 94 & 0,0914 & $\mathrm{H}_{0}$ diterima & $\begin{array}{l}\text { Populasi berdistribusi } \\
\text { normal }\end{array}$ \\
\hline eksperimen 2 & 0,0680 & 100 & 0,0886 & $\mathrm{H}_{0}$ diterima & $\begin{array}{l}\text { Populasi berditribusi } \\
\text { normal }\end{array}$ \\
\hline
\end{tabular}

Tabel 3 Jumlah Siswa Berdasarkan Model Pembelajaran dan Minat Belajar

\begin{tabular}{|l|c|c|c|c|}
\hline \multirow{2}{*}{ Kelompok } & \multicolumn{3}{c|}{ Minat Belajar } & \multirow{2}{*}{ Jumlah } \\
\cline { 2 - 4 } & Tinggi & Sedang & Rendah & \\
\hline Problem Solving & 33 & 31 & 30 & 94 \\
\hline TAI & 28 & 37 & 35 & 100 \\
\hline Jumlah & 61 & 68 & 65 & \\
\hline
\end{tabular}

Tabel 4. Deskripsi Data Prestasi Belajar Berdasarkan Model Pembelajaran

\begin{tabular}{|l|c|c|}
\hline \multirow{2}{*}{\multicolumn{1}{c|}{$\begin{array}{c}\text { Statistik } \\
\text { deskriptif }\end{array}$}} & \multicolumn{2}{c|}{ Kelompok } \\
\cline { 2 - 3 } & Problem Solving & TAI \\
\hline Rata-rata & 72,596 & 68,000 \\
\hline Median & 76,000 & 72,000 \\
\hline Modus & 76,000 & 72,000 \\
\hline Nilai maksimum & 88,000 & 88,000 \\
\hline Nilai minimum & 48,000 & 40,000 \\
\hline Standar deviasi & 11,328 & 13,716 \\
\hline
\end{tabular}


Tabel 5 Deskripsi Data Prestasi Belajar Berdasarkan Tingkat Minat Belajar

\begin{tabular}{|l|c|c|c|}
\hline \multirow{2}{*}{\multicolumn{1}{c|}{$\begin{array}{c}\text { Statistik } \\
\text { deskriptif }\end{array}$}} & \multicolumn{3}{|c|}{ Tingkat Minat Belajar } \\
\cline { 2 - 4 } & Tinggi & Sedang & Rendah \\
\hline Rata-rata & 75,082 & 69,353 & 66,585 \\
\hline Median & 76,000 & 72,000 & 64,000 \\
\hline Modus & 76,000 & 76,000 & 64,000 \\
\hline Nilai maksimum & 88,000 & 88,000 & 88,000 \\
\hline Nilai minimum & 40,000 & 44,000 & 40,000 \\
\hline Standar deviasi & 10,618 & 12,471 & 13,719 \\
\hline
\end{tabular}

Dalam penelitian ini, uji normalitas meliputi uji normalitas untuk kelompok problem solving, kelompok TAI, kelompok dengan minat belajar tinggi, kelompok dengan minat belajar sedang, dan kelompok dengan minat belajar rendah sebagaimana Tabel 6.
Uji homogenitas prestasi belajar yang dilakukan adalah uji homogenitas antar baris, yaitu berdasar model pembelajaran (kelompok problem solving dan kelompok $T A I)$ dan uji homogenitas antar kolom, yaitu berdasar tingkat minat belajar sebagaimana Tabel 7.

Tabel 6 Rangkuman Uji Normalitas Prestasi Belajar

\begin{tabular}{|l|l|l|l|l|l|}
\hline No & Kelompok & $\mathbf{L}_{\text {obs }}$ & $\mathbf{L}_{\text {tabel }}$ & $\begin{array}{l}\text { Keputusan } \\
\text { uji }\end{array}$ & Kesimpulan \\
\hline 1 & Problem Solving & 0,0869 & 0,0914 & $\mathrm{H}_{0}$ diterima & $\begin{array}{l}\text { Populasi berdistribusi } \\
\text { normal }\end{array}$ \\
\hline 2 & TAI & 0,0779 & 0,0886 & $\mathrm{H}_{0}$ diterima & $\begin{array}{l}\text { Populasi berdistribusi } \\
\text { normal }\end{array}$ \\
\hline 4 & $\begin{array}{l}\text { Minat belajar } \\
\text { tinggi }\end{array}$ & 0,1112 & 0,1134 & $\mathrm{H}_{0}$ diterima & $\begin{array}{l}\text { Populasi berdistribusi } \\
\text { normal }\end{array}$ \\
\hline 5 & $\begin{array}{l}\text { Minat belajar } \\
\text { sedang }\end{array}$ & 0,0969 & 0,1074 & $\mathrm{H}_{0}$ diterima & $\begin{array}{l}\text { Populasi berdistribusi } \\
\text { normal b bras bribusi }\end{array}$ \\
\hline 6 & $\begin{array}{l}\text { Minat belajar } \\
\text { rendah }\end{array}$ & 0,0830 & 0,1099 & $\mathrm{H}_{0}$ diterima & $\begin{array}{l}\text { Populasi berdistribus } \\
\text { normal }\end{array}$ \\
\hline
\end{tabular}

Tabel 7 Rangkuman Uji Homogenitas Prestasi Belajar

\begin{tabular}{|l|l|c|c|l|l|}
\hline No. & Uji & $\chi_{\text {obs }}^{2}$ & $\chi_{\text {tabel }}^{2}$ & Keputusan & Ket \\
\hline 1 & Antar baris & 3,4554 & 3,8410 & $\mathrm{H}_{0}$ diterima & Variansi populasi sama \\
\hline 2 & Antar kolom & 3,9874 & 5,9910 & $\mathrm{H}_{0}$ diterima & Variansi populasi sama \\
\hline
\end{tabular}

Tabel 8. Rangkuman Analisis Variansi Dua Jalan Dengan Sel Tak Sama

\begin{tabular}{|c|c|c|c|c|c|c|}
\hline Sumber & JK & dk & RK & $\mathbf{F}_{\text {obs }}$ & $\mathbf{F}_{\text {Tabel }}$ & Keputusan uji \\
\hline $\begin{array}{l}\text { Model } \\
\text { pembelajaran (A) }\end{array}$ & 852,707 & 1 & 852,707 & 5,680 & 3,89 & $\mathrm{H}_{0 \mathrm{~A}}$ ditolak \\
\hline Minat Belajar (B) & 2168,154 & 2 & 1084,077 & 7,222 & 3,04 & $\mathrm{H}_{\mathrm{OB}}$ ditolak \\
\hline Interaksi (AB) & 192,418 & 2 & 96,209 & 0,641 & 3,04 & $\mathrm{H}_{0 \mathrm{AB}}$ diterima \\
\hline Galat $(\mathrm{G})$ & 28221,494 & 188 & 150,114 & & & \\
\hline Total & 31434,772 & 193 & & & & \\
\hline
\end{tabular}

analisis variansi dua jalan $2 \times 3$ dengan sel tidak sama dan taraf signifikansi $\alpha=5 \%$ terdapat pada Lampiran 33, dengan
8.

Berdasarkan Tabel 8 tampak bahwa: 
a. Pada efek utama A (model pembelajaran), harga statistik uji $\mathrm{F}_{\mathrm{A}}=$ 5,680 dan $\mathrm{F}_{\text {tabel }}=3,89$, ternyata $\mathrm{F}_{\mathrm{A}}>$ $\mathrm{F}_{\text {tabel }}$ dengan demikian $\mathrm{H}_{0 \mathrm{~A}}$ ditolak. Hal ini berarti pada tingkat signifikansi $\alpha=$ $5 \%$ terdapat perbedaan prestasi belajar antara model pembelajaran kooperatif tipe problem solving dan model pembelajaran kooperatif tipe TAI.

b. Pada efek utama B (tingkat minat belajar siswa), harga statistik uji $\mathrm{F}_{\mathrm{B}}=$ 7,222 dan $F_{\text {tabel }}=3,04$, ternyata $F_{B}>$ $\mathrm{F}_{\text {tabel }}$ dengan demikian $\mathrm{H}_{0 \mathrm{~B}}$ ditolak. Hal ini berarti pada tingkat signifikansi $\alpha=$ $5 \%$ tingkat minat belajar siswa yang tinggi, sedang maupun rendah memberikan efek yang berbeda terhadap prestasi belajar matematika.

c. Pada efek interaksi AB (model pembelajaran dan tingkat minat belajar siswa), harga statistik uji $\mathrm{F}_{\mathrm{AB}}=0,641$ dan $\mathrm{F}_{\text {tabel }}=3,04$, ternyata $\mathrm{F}_{\mathrm{AB}}<\mathrm{F}_{\text {tabel }}$ dengan demikian $\mathrm{H}_{0 \mathrm{AB}}$ diterima. Hal ini berarti pada tingkat signifikan $\alpha=5 \%$ tidak terdapat interaksi antara model pembelajaran dan tingkat minat belajar siswa terhadap prestasi belajar matematika.

\section{Uji Lanjut Pasca Anava}

Sebelum melakukan uji lanjut pasca anava, pada Tabel 9 disajikan rangkuman rerata antar sel lengkap dengan rerata marginalnya.

Berdasarkan hasil analisis variansi dua jalan dengan sel tak sama diperoleh bahwa $\mathrm{H}_{0 \mathrm{~A}}$ dan $\mathrm{H}_{0 \mathrm{~B}}$ ditolak. Untuk $\mathrm{H}_{0 \mathrm{~A}}$, cukup dengan membandingkan rerata marginal baris pertama dengan baris kedua. Untuk $\mathrm{H}_{0 \mathrm{~B}}$ dilakukan uji lanjut untuk melacak perbedaan rerata. Dalam penelitian ini uji lanjut menggunakan uji komparasi ganda dengan metode Scheffe's sebagaimna Tabel 10.

Tabel 9. Rerata Prestasi Belajar Berdasar Model Pembelajaran dan Minat Belajar

\begin{tabular}{|l|c|c|c|c|}
\hline \multirow{2}{*}{ Kelompok } & \multicolumn{3}{|c|}{ Minat Belajar } & \multirow{2}{*}{ Rerata Marginal } \\
\cline { 2 - 4 } & Tinggi & Sedang & Rendah & \\
\hline Problem Solving & 78,303 & 70,710 & 68,267 & 72,596 \\
\hline TAI & 71,286 & 68,216 & 65,143 & 68,000 \\
\hline Rerata marginal & 75,082 & 69,353 & 66,585 & \\
\hline
\end{tabular}

Tabel 10 Rangkuman Uji Komparasi Antar Kolom

\begin{tabular}{|l|l|l|l|}
\hline $\mathbf{H}_{\mathbf{0}}$ & $\mathbf{F}_{\text {obs }}$ & $\mathbf{F}=\mathbf{2 F _ { \text { tabel } }}$ & Keputusan Uji \\
\hline$\mu_{\cdot 1}=\mu_{\cdot 2}$ & 7,0304 & 6,00 & $\mathrm{H}_{0}$ ditolak \\
\hline$\mu_{\cdot 1}=\mu_{\cdot 3}$ & 15,1258 & 6,00 & $\mathrm{H}_{0}$ ditolak \\
\hline$\mu_{\cdot 2}=\mu_{\cdot 3}$ & 1,6961 & 6,00 & $\mathrm{H}_{0}$ diterima \\
\hline
\end{tabular}

\section{Keterangan:}

$\mu_{.1}$ : rerata prestasi belajar matematika untuk minat belajar tinggi

$\mu_{.2}$ : rerata prestasi belajar matematika untuk minat belajar sedang

$\mu_{.3}$ : rerata prestasi belajar matematika untuk minat belajar rendah

Berdasarkan hasil perhitungan uji

KESIMPULAN komparasi rataan antar kolom, diperoleh kesimpulan yaitu: 
1. $\mu_{.1} \neq \mu_{.2}\left(\mathrm{H}_{0}\right.$ ditolak $)$. Ini berarti ada perbedaan terhadap prestasi belajar jika dilihat dari minat belajar siswa. Dari tabel rerata marginal dapat disimpulkan bahwa siswa yang mempunyai minat belajar tinggi mempunyai prestasi belajar lebih baik jika dibandingkan dengan siswa yang mempunyai minat belajar sedang.

2. $\mu_{.1} \neq \mu_{\cdot 3}\left(\mathrm{H}_{0}\right.$ ditolak $)$, yang artinya terdapat perbedaan hasil belajar antara siswa yang mempunyai minat belajar tinggi dibandingkan dengan siswa yang mempunyai minat belajar rendah. Dapat dilihat dari tabel rataan marginal bahwa siswa yang minat belajarnya tinggi mempunyai hasil belajar yang lebih baik dibandingkan dengan siswa yang mempunyai minat belajar rendah.

3. $\mu_{\cdot_{2}}=\mu_{\cdot 3}\left(\mathrm{H}_{0}\right.$ diterima $)$. Ini berarti tidak ada perbedaan hasil belajar antara siswa yang mempunyai minat belajar sedang dengan siswa yang mempunyai minat belajar rendah. Perhitungan uji komparasi ganda selengkapnya dapat dilihat pada Lampiran 34.

\section{Implikasi}

\section{Implikasi Teoritis}

Berikut merupakan implikasi teoritis yang diperoleh berdasarkan kesimpulan:

a. Model pembelajaran kooperatif merupakan suatu model pembelajaran yang yang menerapkan kerjasama. Penerapan model pembelajaran ini, terutama untuk model pembelajaran problem solving perlu dikaji dan dilaksanakan karena dapat menghasilkan prestasi belajar siswa yang lebih baik.

b. Peningkatan minat belajar siswa di sekolah perlu diperhatikan karena minat belajar siswa berpengaruh terhadap prestasi belajar, siswa dengan minat belajar tinggi mempunyai prestasi belajar yang lebih baik.

\section{Implikasi Praktis}

Untuk meningkatkan prestasi belajar siswa Kelas VII SMP Kabupaten Rembang dapat dilakukan melalui pembelajaran kooperatif, salah satunya tipe problem solving. Selain itu, perlu dikembangkan pula lingkungan yang kondusif yang dapat mempengaruhi meningkatnya minat belajar siswa. Siswa yang mempunyai minat belajar tinggi, akan berpengaruh pada kreativitas diri siswa sehingga hasil karya diri siswa dapat meningkat dan tidak terkecuali prestasi belajarnya.

\section{Saran}

Berdasarkan penelitian ini dapat dikemukakan beberapa saran sebagai berikut:

a. Guru dan Kepala Sekolah perlu menerapkan model pembelajaran kooperatif pada pembelajaran matematika karena dapat menghasilkan prestasi belajar siswa yang lebih baik khususnya model pembelajaran Problem Solving.

b. Guru dan Kepala Sekolah perlu menciptakan kondisi lingkungan yang kondusif dan positif karena interaksi 
dengan lingkungan di sekitar, dapat mempengaruhi minat belajar siswa, sehingga dimungkinkan akan terjadi peningkatan pencapaian prestasi belajar siswa.

c. Peneliti lain, dapat mengembangkan hasil penelitian ini sebagai salah satu referensi untuk penelitian yang relevan. Para peneliti dapat mengembangkan penelitian untuk variabel lain yang sejenis atau model pembelajaran lain. Untuk penelitian lanjut, diharapkan para peneliti dapat memilih model pembelajaran yang tidak hanya untuk meningkatkan prestasi belajar, tetapi juga untuk meningkatkan minat belajar siswa.

\section{DAFTAR PUSTAKA}

Abu Ahmadi,. 1992. Psikologi Umum. Jakarta: Rineka Cipta.

Adeyemi, B. 2008. Effects of Cooperative Learning and Problem Solving Strategies on Junior Secondary School students' Achievement in Social Studies. Electronic Journal of Research in Educational Psychology, v6, n3, p691-708.

Agus Suprijono. 2009. Cooperative Learning. Teori dan Aplikasi Paikem. Yogyakarta : Pustaka Pelajar.

Amin Suyitno. 2006. Dasar-Dasar dan Proses Pembelajaran Matematika I. Semarang: Jurusan Matematika FMIPA UNNES.

Anas Sudijono. 2007. Pengantar Evaluasi Pendidikan. Jakarta: PT Raja Grafindo Persada.

Anita Lie. 2002. Cooperative Learning. Jakarta: Grasindo.

Ballantine, J dan Larres, P. 2007. Cooperative learning: A Pedagogy to
Improve Students Generic Skills? Journal Articles; Reports- Evaluative. Education \& Training, v49, n2, p126137.

Budiyono. 2003. Metodologi Penelitian Pendidikan. Surakarta: UNS Press.

Budiyono. 2009. Statistika Untuk Penelitian Edisi Ke-2. : UNS Press.

Depdiknas. 2003. Standar Kompetensi Mata Pelajaran Matematika SMP/MTs. Jakarta:Pusat Kurikulum, Balitbang Depdiknas.

Depdiknas. 2006. Peraturan Menteri Pendidikan Nasional Nomor 98 2006 Tanggal 23 Mei 201 Isi. Jakarta: Departemen rendıdıkan Nasional.

Djamarah, Syaiful Bahri.2000. Psikologi Belajar. Banjarmasin : Rineka Cipta.

Doymus, K. 2007. Effects of a Cooperative Learning Strategy and Learning Phases of Matter and One-Component Phase Diagrams. Journal of Chemical Education, v84, n11, p1857-1860.

Enco Mulyasa. 2003. Kurikulum Berbasis Kompetensi. Bandung: Remaja Rosdakarya.

Erman Suherman. 2003. Strategi Pembelajaran Matematika Kontemporer. Bandung: JICAIMSTEP.

Erman Suherman. 2009. Model Belajar dan Pembelajaran Berorientasi Kompetensi Siswa. EDUCARE: Jurnal pe in dan Budaya. Diunduh ...ri http://www.educare.e-fkipunla.net tanggal 25 mei 2009.

Fitri Nur Rohmah. 2005. Eksperimentasi Pengajaran Matematika Dengan Model Kontruktivisme Pada Pokok Bahasan Bangun Ruang Ditinjau Dari Aktivitas Belajar Siswa. Tesis. Program Studi Pendidikan Matematika Program 
Pascasarjana Universitas Sebelas Maret Surakarta.

Gillies, Robyn M., Boyle, Michael. 2010. (School of Education, The University of Queensland, Brisbane, Queensland 4072, Australia). Teachers' reflections on cooperative learning: Issues of implementation. Journal of Teaching \& Teacher Education; May2010, Vol. 26 Issue 4, p933-940, 8p.

Hornby, G. 2009. The effectiveness of cooperative learning with trainee teachers. Journal of Education for Teaching, Volume 35, Issue 2 May 2009 , pages $161-168$.

Ibrahim, dkk. 2000. Pembelajaran Kooperatif. Surabaya: UNESA.

Isjoni. 2009. Cooperative learning: Mengembangkan Kemampuan Belajar Berkelompok. Bandung: Alfabeta.

Lisnawaty Simanjuntak, dkk. 1993. Metode Mengajar Matematika. Jakarta: Rineka Cipta.

Maria Purwaningsih. 2008. Hubungan antara Konsep Diri dan Prestasi Belajar Matematika Siswa Kelas IX sebuah SMP Swasta di Kabupaten Semarang. Jurnal Widya Sari. Vol. 15. No 9. Hal. 96-108.

Maswins. 2010, 20 Juni. Pengertian matematika. : http://Maswins.com//

Muhibbin Syah. 2003. Psikologi Belajar. Jakarta: Rajawali Pers.

Mujapar. 2010. Eksperimentasi pembelajaran matematika dengan metode jigsaw pada pokok bahasan peluang ditinjau dari motivasi belajar siswa kelas XI ilmu pengetahuan alam SMA Negeri Surakarta. Tesis. Prodi Pendidikan Matematika Program Pasca Sarjana UNS, Surakarta.

M.Wahid Syaifuddin. 2010. Eksperimentasi model pembelajaran kooperatif tipe teams assisted individualization (TAI) pada pokok bahasan relasi dan fungsi ditinjau dari kemampuan awal siswa kelas VIII MTs Kabupaten Klaten tahun pelajaran 2009/2010. Tesis. Prodi Pendidikan Matematika Program Pasca Sarjana UNS, Surakarta.

Nanang Hanafiah dan Cucu Suhana. 2009. Konsep Strategi Pembelajaran. Bandung: Refika Aditama.

Otong Kardisaputra. Penelitian tentang manfaat tujuan pembelajaran khusus dalam proses belajar mengajar.

http://educare.efkinpula.net/index.php?optio $\underline{\mathrm{n}=\mathrm{com}}$

Partono. 2009. Pengaruh Model Pembelajaran Kontekstual Terhadap Prestasi Belajar Barisan Dan Deret Ditinjau Dari Kemampuan Awal. Tesis. Program Studi Pendidikan Matematika Program Pascasarjana Universitas Sebelas Maret Surakarta.

Slameto, 1991. Belajar dan Faktor yang Mempengaruhinya. Jakarta: Rineka Cipta

Slameto. 2003. Belajar dan Faktor-faktor yang Mempengaruhinya. Jakarta : Rineka Cipta.

Slavin, R. E. 1995. Cooperative Learning: Theory, Research and Practice. Second Edition. Boston: Ally and Bacon.

Slavin, R. E. 2010. Cooprative Learning: Teori, Riset, dan Praktik. Cetakan VI. Bandung: Nusa Media.

Sutratinah Tirtonegoro. 2001. Anak Supernormal dan Program Pendidikannya. Jakarta: Bumi Aksara.

Suyadi. 2009. Eksperimentasi Model Pembelajaran Pemecahan Masalah (PROBLEM SOLVING) Pada Materi Pokok Lingkaran Terhadap Prestasi Belajar Matematika Ditinjau Dari Motivasi Belajar Pada Siswa Kelas 8 SMP Di Kabupaten Sragen. Laporan Penelitian Thesis UNS. Program 
Pendidikan Matematika Program Pascasarjana Universitas Sebelas Maret

The Liang Gie. 1995. Cara Belajar Yang Efisien Jilid II. Yogyakarta: Liberty
www.Zainurie.wordpress.com. 2009. "Pakar Matematika" Bicara Tentang, Prestasi Pendidikan Matematika Indonesia. Diakses pada tanggal 5-122009 pukul 14:02. 